Section Editor Mitchell S.V. Elkind, MD, MS

Thanos D. Papakostas, $\mathrm{MD}$

Simmons Lessell, MD

Correspondence to Dr. Papakostas: thanos_papakostas@meei.harvard. edu

\title{
Teaching Video NeuroImages: Pulsatile proptosis
}

昌

A 44-year-old man with neurofibromatosis type 1 had been aware that his right eye pulsated. His visual acuity was 20/15 in both eyes and his intraocular pressures were normal. He had $4 \mathrm{~mm}$ of right exophthalmos and there was pulsesynchronous pulsation of the right eye (video on the Neurology ${ }^{\circledR}$ Web site at www.neurology.org). No bruit was heard. Lisch nodules were present on both irides. CT showed a large osseous defect of the greater wing of the right sphenoid bone. The differential diagnosis of pulsatile proptosis includes absence of the sphenoid wing in patients with neurofibromatosis $1,{ }^{1}$ carotid-cavernous fistula, orbital roof fractures, and arteriovenous malformations. $^{2}$

\section{AUTHOR CONTRIBUTIONS}

Thanos Papakostas: drafting/revising the manuscript, study concept or design, analysis or interpretation of data, accepts responsibility for conduct of research and final approval, acquisition of data. Simmons Lessell: drafting/revising the manuscript, study concept or design, analysis or interpretation of data, accepts responsibility for conduct of research and final approval.

\section{STUDY FUNDING}

No targeted funding reported.

\section{DISCLOSURE}

The authors report no disclosures relevant to the manuscript. Go to Neurology.org for full disclosures.

\section{REFERENCES}

1. Wiesenfeld D, James PL. Pulsating exophthalmos associated with neurofibromatosis. J Maxillofac Surg 1984;12:11-13.

2. Schellenbeck R. Zur Differentialdiagnose des Exophthalmus pulsans. Klin Monatsbl Augenheilkd 1980;176:991-992. 


\title{
Neurology
}

\author{
Teaching Video NeuroImages: Pulsatile proptosis \\ Thanos D. Papakostas and Simmons Lessell \\ Neurology 2013;81;e160 \\ DOI 10.1212/01.wnl.0000436066.35760.24
}

This information is current as of November 18, 2013

\section{Updated Information \& Services}

Supplementary Material

\section{References}

Subspecialty Collections

Permissions \& Licensing

Reprints including high resolution figures, can be found at: http://n.neurology.org/content/81/21/e160.full

Supplementary material can be found at: http://n.neurology.org/content/suppl/2013/11/17/81.21.e160.DC1 http://n.neurology.org/content/supp1/2013/11/17/81.21.e160.DC2

This article cites 2 articles, 0 of which you can access for free at: http://n.neurology.org/content/81/21/e160.full\#ref-list-1

This article, along with others on similar topics, appears in the following collection(s):

Neurofibromatosis

http://n.neurology.org/cgi/collection/neurofibromatosis

Information about reproducing this article in parts (figures,tables) or in its entirety can be found online at:

http://www.neurology.org/about/about_the_journal\#permissions

Information about ordering reprints can be found online:

http://n.neurology.org/subscribers/advertise

Neurology ${ }^{\circledR}$ is the official journal of the American Academy of Neurology. Published continuously since 1951, it is now a weekly with 48 issues per year. Copyright @ 2013 American Academy of Neurology. All rights reserved. Print ISSN: 0028-3878. Online ISSN: 1526-632X.

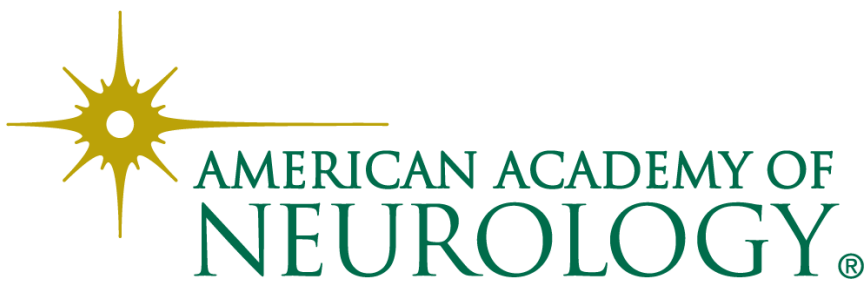

